\title{
Olympiske Lege - et forhindringsløb for kvinder
}

\author{
af Else Trangboek
}

125 danske kvinder har siden 1920 deltaget i de olympiske konkurrencer. Selvom det ikke drejer sig om så mange kvinder, er deres historie interessant, da den kan være med til at synliggøre de grænser i sportens verden, kvinder har skullet overskride for at få lov at lege i en verden skabt af og til mænd. Disse kvinders oplevelser, erfaringer og livshistorie ville jeg gerne have fortalt. Men, ak - projektet er endnu ikke blevet gennemført, hvorfor der her kun vil blive sat af fra en af de 125 kvinders oplevelser. I 1968 deltog jeg selv ved OL i Mexico, som eneste danske kvindelige gymnast, ikke som stjerne men, som en blandt de mange andre gymnaster, der var med til at danne »hof « omkring de rigtige stjerner og med til at sætte deres præstationer i et passende relief. Interessant var det, og mange historier kunne fortælles i den anledning. Jeg vil dog her fors $\varnothing$ ge at se i bakspejlet efter oplevelser, som har speciel kvindehistorisk og/eller eliteidrætshistorisk interesse.

Den danske trup på i alt 72 aktive deltagere bestod af 4 kvinder. Vi boede sammen med alle de andre kvindelige deltagere i OL-byens »kvindelejr « godt beskyttet af ståltrådshegn, og godt bevogtet af kvindelige politibetjente. Der måtte nogen til at passe på os SVAGE piger.

I god tid inden konkurrencerne ankom vi til Mexico City, for at blive akklimatiseret, og dagene gik således med træning, udflugter, deltagelse i forskellige repræsentative arrangementer og samvær på tværs af køn og landegrænser. For de aktive, som havde blot rimelige placeringschancer var dagene præget af mindre variation, idet de i det væsentligste trænede og hyggede sig i OL-byen, men i modsætning til mig var de til gengæld så gode, at de havde fået en eller flere trænere med. I dag - kun 20 år efter - hvor støttemulighederne via Team Danmark og Dansk Olympisk Komite er meget veludbyggede, kan jeg godt undre mig over, at jeg blev sendt af sted i 5 uger uden en træner. Med lidt planlægning på stedet gik det dog alligevel. I begyndelsen fik jeg støtte af en af de mandlige gymnaster, Hans Peter Nielsen, og senere lyk- 
kedes det at blive knyttet til de svenske gymnasters træning. Jeg havde ellers modtaget et, for en dansk gymnast meget spændende tilbud, at træne med de østtyske gymnaster. Men, desværre, jeg fik ikke lov, idet vi fra dansk side var blevet "forbudt « at blande os med Sovjet og DDR p.g.a. den sovjetiske invasion i Tjekkoslovakiet sommeren 1968. Det var ikke de eneste politiske undertoner, jeg oplevede i Mexico. Voldsomme studenterdemonstrationer, som protest mod regeringens $\emptyset$ konomiske og sociale politik og afholdelsen af

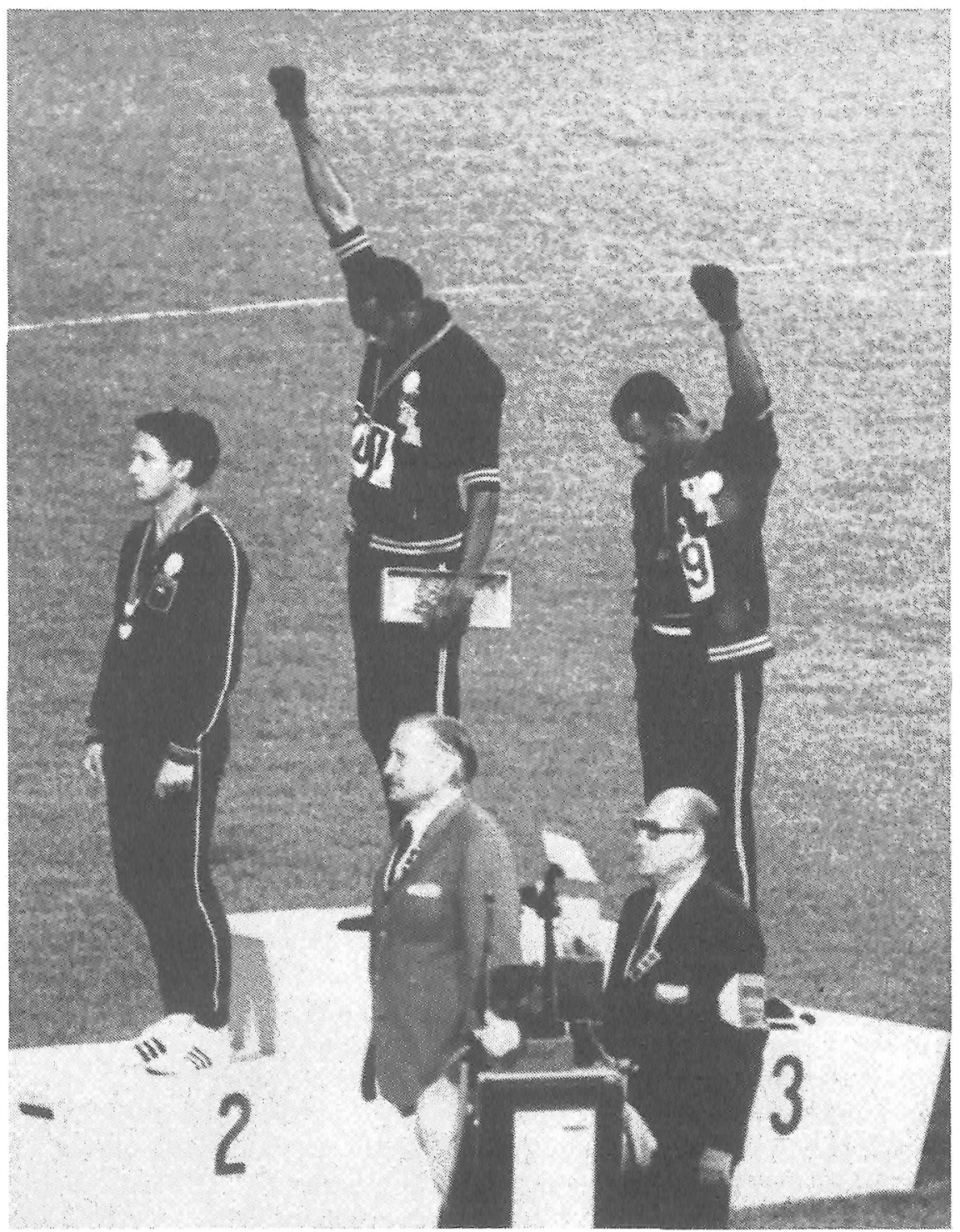


de kostbare olympiske lege, kulminerede den 2. oktober kort før legenes åbning, i en stor demonstration, der kostede mange menneskeliv. Jeg mindes ikke, vi blev egentlig informeret om disse begivenheder, udover at der blev udstedt forbud mod at forlade den olympiske by uden tilladelse. På idrætsbanen blev politikken ført helt frem til sejrsskamlerne af Tommie Smith og John Carlos, henholdsvis guld og bronze vinder i 200 meter $1 \varnothing b$, da de under sejrsceremonien viste blackpower hilsen.

En af de for mig meget sjove fritidssysler var at ligge på maven på sofaen i vores lejlighed og se ud på et af de centrale »strøg « i OL byen. Her iagttog jeg de forskellige persontyper og gættede på, i hvilke discipliner de pågældende skulle deltage. Den specialiserede idræt kræver specialiserede kroppe, og hver krop havde sin egen kropshistorie. Således kom jeg også for skade en dag, da jeg var i biografen, at bede en fyr, der sad foran mig om at sætte sig ned på sædet, idet jeg troede, han sad på ryglænet. Ved min lette prikken på ryggen rejste han sig op, og jeg måtte konstatere, at det var en af de sovjetiske basketspillere på godt 2 meter, som havde siddet pænt på sædet.

OL er noget specielt. De mange idrætsfolk fra forskellige lande dækkende forskellige aktiviteter gør OL til en uforglemmelig oplevelse. For mig har det udover de idrætslige og sociale oplevelser betydet, at jeg senere som idrætsleder og i mit arbejde som idrætshistoriker og idrætsunderviser har fået nogle meget konkrete oplevelser på emnerne: idræt og specialisering, idræt og politik, idræt og medier, kvinder og idræt m.m. Idrættens mange modsætninger blev gjort åbenlyse for mig bl.a. i forbindelse med min OL-deltagelse. Eliteidrætten har på den ene side givet mig store personlige og kollektive udfordringer og oplevelser, og på den anden side skærpet min opmærksomhed på mange af de problemer, der opstår, når idrætten lader sig bruge og misbruge.

Jeg ville gerne have talt med de nulevende af de 125. OL-kvinder om: Hvad de har kunnet bruge idrættens mange udfordringer til i deres senere liv? Hvori lå disse kvinders potentialer? Hvad var det, der gjorde, at de magtede at overskride grænser, som mange andre kvinder måtte stå af overfor? Hvordan havde deres idrætslige opdragelse været? Hvilke modsætninger oplevede de i idrætten? osv.

Disse kvinders historie kan på den ene side fortælle om kvinder og OL, men de 125 kvinder er også en god og velafgrænset gruppe, til at begynde at tage fat på eliteidrætshistorien, både som fascinationshistorie og den historie, der ser på sportens ekspansion med hensyn til træningsmetoder, udstyr, tidsanvendelse, træningssteder, trænere m.m.

Jeg startede med at fortælle, at vi boede bag »kvindelejrens « pigtrådshegn. Ingen mænd måtte komme i kvindehusene, hos det SVAGE køn, undtagen 
de læger, som skulle teste, om der blandt de SVAGE piger skulle befinde sig nogle som var for STÆRKE. For første gang i OL-historien måtte samtlige piger lade sig underkaste en kønstest, for at få lov til at deltage i konkurrencerne. Man måtte have kasseret de altfor STÆRKE piger.

Med et lille slimudtræk fra mundhulen blev der stillet spørgsmålstegn ved kvindernes biologi. Som et kuriosum har jeg fundet min egen kønstest frem fra 1968, og jeg kan med tilfredshed konstatere, at jeg ikke lider af sygdommen sexuel abnormitet - hvad det så end betyder.

A L'OCCASION DES JEUX DE LA XIX E OLYMPIADE IL A ETE PROCEDE SUR: ON OCCASION OF THE XIX OLYMPIC GAMES ON

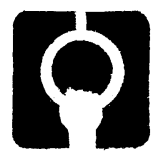

L'ATHLETE

THE ATHLETE TRANGBAEK ELSE

SPORT:

SPORT

GIMNASIA

CARTE D'IDENTITE:

IDENTITY CARD

114717

NATIONALITE:

NATIONALITY

DINAMARCA

A UN EXAMEN DE CHROM $\triangle$ TINE SEXUELLE QUI N'A DONNE AUCUNE ANOMALIE.

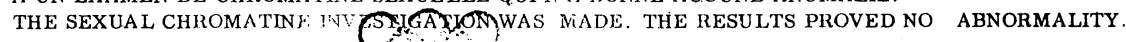

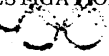

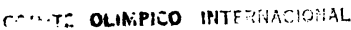

COMMISSION MEDICALE DU C.I.O.

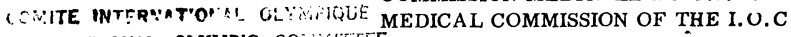

Timis flux. U Mlexg INTERNATIONAL OLYMPIC COIMITTTEE

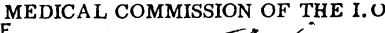

COMUSION MEDICA DEL. C.. 0.1.

COMMISSION MEOICALE DU C. I. 0.

MEDICAL BOARD OF THE I. O.C.

LE PRESIDENT DE LA COMMISSION MEDICALE THE CHAIRMAN OF THE MEDICAL COMMISSION

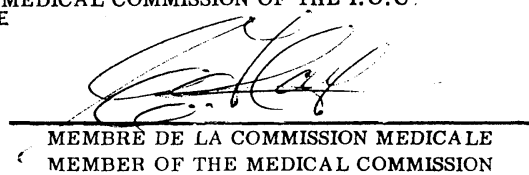

\section{Sporten og kvinden}

De olympiske leges genopståen i 1896 var knyttet tæt sammen med sportens gennembrud i slutningen af forrige århundrede og for begges vedkommende var der stort set tale om en enkønnet bevægelse (1). Skaberen af de moderne olympiske lege Pierre de Coubertin markerer klart sin holdning til kvinders rolle i forbindelse med OL i nævnte citat fra sine erindringer (2).

"I personally am against the participation of women in public competitions, which does not mean that they should not participate in sports, yet not in public. At the Olympic Games their primary role should be like in the ancient tournaments - the crowning af the (male) victors with laurels. 
Når Coubertin var så hård modstander, skal man ikke glemme, at hans drøm var at genskabe de græske OL. Her deltog kvinder ikke. Hvorfor skulle de så deltage nu? Dertil kom, at Coubertin fandt, at kvindeidræt var imod »Laws of Nature «. Han fandt den uæstetisk og argumenterede endvidere med, at kvinder jo aldrig ville kunne blive deltagere $\mathrm{i}$ alle discipliner. Blandt de uæstetiske sportsgrene nævnte han: fægtning, ridning, roning, idet han frygtede, at kvindernes deltagelse ville medføre en feminisering af den ædle kunst, og dette ville lede til dens undergang (3).

Kvindens naturlove bliver ikke her tolket, som snævert sammenhængende med hendes kvindelige biologi, men i højere grad de æstetiske normer og holdningen til kvindens rolle i samfundet.

Sportens kvaliteter var knyttet til udviklingen af en stålsat karakter, med vægt på: »Selvfornægtelse, Udholdenhed, Snarraadighed, Mod, Omløb i Hovedet og potenseret Viljekraft« (4).

De nævnte karakteregenskaber kvalificerede til et aktivt fremadstræbende liv præget af kontakten til og medvirken i den offentlige og samfundsmæssige udvikling. Sporten var skabt af mænd til mænd. Kvinders liv var derimod primært knyttet til privatsfæren, og opfattelsen af hendes muligheder var i høj grad knyttet til biologien. Kvindens liv blev opfattet som en biologisk proces og som en naturlig livscyklus (5). Synet på kvinden var naturligvis ikke entydigt, men udgangspunktet var, at kvinden var svagelig.

Den »biologiske kvinde « og sportens ideal var umiddelbart to uforenelige størrelser, hvorimod en fysiologisk og æstetisk orienteret gymnastik bedre passede til opfattelsen af, hvad kvinden kunne og burde. Den danske læge Fr. Howitz's »Bidrag til en Sundhedslære for kvinder « fra 1892 illustrerer en karakteristisk opfattelse af begrænsningerne med hensyn til fysiske udfoldelser for kvinder (6):

»..det Uheldige - seet fra en Gynakologs Standpunkt - ved flere Arter af vor Tids Sport. Svømning, Riden, Bicycleren, Skøiteløb, alle indeholder visse gynakologiske Farer, naar de drives på uheldig Maade«.

Howitz så derimod med lidt blidere øjne på gymnastikken (7):

».fornuftig ledet Gymnastik«,...»Bevagelser $i$ den fri luft... saa vil hendes Holdning blive rank og hendes figur god .

Vi kan dog i dag konstatere, at kvinder på trods af Coubertins holdning, lægernes advarsler og sportens maskuline karakter deltager i sporten og de olympiske lege. Hvordan lykkedes det egentligt kvinderne at komme med? 


\section{Det internationale forhindringsløb}

Kvinderne deltog for første gang i OL i 1900 i tennis og bueskydning, men det skulle vise sig at blive en lang vej via overbevisning og dokumentation frem mod det billede, vi kender i dag.

For de aktive kvinder, der kæmpede for OL-deltagelse, handlede perioden frem til 1920 primært om at skabe troen på, at det kunne lykkes. Få - og stærke kvinder - fors $\emptyset$ gte at være identifikationsmodeller for andre kvinder, for derved at give dem tro på, at sport og her OL-sport også havde væsentlige kvaliteter for kvinder.

I 1917 oprettede nogle franske kvinder en national kvindeidrætsorganisation, og de fors $\emptyset g t e$ at få IOC til at optage atletik for kvinder på OL-programmet i 1920. Henvendelsen og initiativet medførte, at Coubertin foreslog at udelukke alle kvindediscipliner ved OL, hvilket dog ikke skete, men forslaget blev forkastet. IOCs afslag var bl.a. medvirkende til, at der i 1921 blev oprettet en international kvindesports organisation (Federation Sportive Feminine Internationale), og at de første »Womens Olympic Games «blev afholdt i Paris 1922. Kvindelegene blev en succes, vurderet udfra stigning i antal nationer. Der deltog således ved de sidste separate mesterskaber i 1934 i London i alt 19 nationer. Hidtil havde konkurrencerne kun omhandlet atletik, men i 1934 var basketball og hazena (en forløber for moderne markhåndbold) med på programmet. Ved OL i Berlin i 1936 kom både basket og håndbold på programmet for mænd, hvilket fra flere forskeres side er blevet tolket som udtryk for IOC's angst for, at disse discipliner skulle blive opfattet som kvindediscipliner. Kvindernes modkultur havde ikke været forgæves. I 1928 havde IOC optaget atletik på programmet, og 101 kvinder fra 18 nationer deltog i konkurrencerne (8).

De første forhindringer var overstået. Trods ihærdige fors $\varnothing \mathrm{g}$ på at ændre opfattelsen af kvindesportens æstetik var det kun delvist lykkedes, og dertil kom, at kvinderne fortsat blev betragtet som relativ svage og derfor mindre velegnede til sport end mænd. Frem til 1952 konsoliderede kvinderne dog deres position i OL-sammenhænge, medens der i perioden herefter skete de egentlige kvalitative forandringer med udgangspunkt i de biologiske grænser.

De østeuropæiske kvinders indtog i OL sammenhænge var med til at få udviklingen til at accelerere, idet de, på lige fod med mændene, blev underlagt en meget specialiseret træning og meget optimale træningsbetingelser (9). Eliteidrættens kvinder begyndte herefter med øget hastighed at nedbryde de biologiske myter om kvindens naturlige livscyklus, i deres $\emptyset$ nske om at kunne leve op til idealet: »Hurtigere, højere og stærkere $«$. 


\section{Udviklingen af det olympiske program for kvinder $\mathbf{x}$ )}

$\begin{array}{llllllllllllllllllll}1900 & 1904 & 1908 & 1912 & 1920 & 1924 & 1928 & 1932 & 1936 & 1948 & 1952 & 1956 & 1960 & 1964 & 1968 & 1972 & 1976 & 1980 & 1984 & 1988\end{array}$

Golf

Tennis

Bueskydning

Kunstskøjteløb

Svømning

Fægtning

Gymnastik

Atletik

Alpin skiløb

Kano

Langrend

Hurtigløb på sk øjter

Kælk

Volleyball

Basketball

Håndbold

Roning

Bordtennis

470 - jolle

Total Number

of Sports

$$
+
$$

$+$

$+$

$+$

$14 \quad 13$

$21 \quad 15$

20

$17 \quad 17$

$14 \quad 2$

19

$19 \quad 20$

$18 \quad 18$

18

$23 \quad 23$

O Oversigten er lavet på baggrund af tabel nr. 1 i Women at the Olympic Games og oplysninger fra Dansk Olympiske Komite. 


\section{De biologiske myter}

Troen på, at kvinden var svagelig og dermed mindre velegnet til sport end manden, var i begyndelsen af århundredet udgangspunktet, og med støtte fra den opvoksende videnskab kom der tal på svagheden, idet det kunne dokumenteres, at kvinders styrke rent fysisk kun udgjorde en vis procentdel af mænds styrke. Derfor kom en del af kvindernes kamp (i denne forbindelse oftest udført af mænd) for at måtte lege med i sportens verden naturligt til at dreje sig om at dokumentere, at denne procentdel er en foranderlig størrelse. Og det er lykkedes. Nedenstående eksempel viser fremgangen i verdensrekorder i $100 \mathrm{~m}$ crawl for mænd og kvinder, og den kan fint illustrere den udvikling, der generelt har været i præstationsudviklingen for begge $k \emptyset n$. (10)

\section{Udviklingen af verdensrekorderne i 100 $\mathrm{m}$ crawl:}

$\begin{array}{lcccc} & 1948 & 1958 & 1968 & 1978 \\ \text { Kvinder } & 1: 04,60 & 1: 01,20 & 0: 58,90 & 0: 55,41 \\ \text { Mænd } & 0: 55,40 & 0: 54,60 & 0: 52,20 & 0: 49,44\end{array}$

Tiderne er angivet i minutter og sekunder.

Metoden er udmærket til at dokumentere, at biologi, også kvinders, er en foranderlig og dermed historisk st $\varnothing$ rrelse, men denne dokumentation bør følges op af årsagsforklaringer. Udviklingen i sporten, her forstået som resultatforbedringer som tegn på sportens kvalitative udvikling, fremstilles ofte som en naturlov, og ikke som et produkt af den samfundsmæssige udvikling. Variable som udvikling i teknologi med hensyn til udstyr og beklædning, træningsmetoder, træningsbetingelser og den samfundsmæssige forståelse og forventning til elitesport må hele tiden følge kvantificeringerne op. Kvindesportens udvikling og kvalificering er således knyttet snævert sammen med mange variable, hvor den generelle forståelse i samfundet for kvindens rolle, som andet end moder og hustru, måske vejer tungest. Den større accept for kvindesporten er således skabt i en konstant dialog mellem kvindefrig ørelsen generelt, og dokumentationen af de videnskabelige data.

De gynækologiske problemer og ikke mindst menstruationen har ofte været årsag til opfattelsen af kvinden som mindre velegnet til sport. Menstruationen blev opfattet som en form for sygdom, der stillede krav om, at sporten måtte ophøre. Denne sygdomstankegang, som lægerne havde hyllet kvinderne ind i, var især henvendt til borgerskabets kvinder. Arbejderkvinder og kvinderne i landbosamfundet havde forlængst kunnet afdække myten om menstruationens krav om fysisk inaktivitet, så man havde ikke behøvet at gå den naturvidenskabelige vej for at afkræfte denne fordom.

Videnskabelige undersøgelser har siden kunne nuancere synsvinklerne, idet nogle kvinders ydeevne faktisk forbedres under menstruation, andres forrin- 
ges, mens der for store gruppers vedkommende end ikke kan registreres forskel (11).

Myten om menstruationen som en hindring for udøvelsen af fysisk aktivitet er således ikke længere et problem for sportskvinden. Når og hvis menstruationen i dag nævnes som et problem, skyldes det i højere grad, at kvinder indenfor visse af elitesportens discipliner har underlagt sig så hårde træningsbelastninger, at menstruationen helt bortfalder (12).

Kvindesportens voldsomme ekspansion har medført, at nogle forskere taler om en »ny type af kvinder «, mens andre mener, at »der er tale om et nyt $k ø n \ll$, og endnu nogle fors $\varnothing$ ger at forklare, at det »nye $k \varnothing n$ « er opstået som en naturlig selektion. Teorierne om det »nye «ved sportskvinden er udsprunget af modsætningerne mellem troen på kvindens naturlige livscyklus som dominerende for hendes livsmuligheder og kvindesportens succes med hensyn til opbakning og resultatudvikling. Kvinden har i sporten bevist, at hun er andet end biologi. Kvindernes resultater har derfor også fået tvivlerne på denne sandhed til at spørge: Er det mon en rigtig og normal kvinde?

Som resultatet af denne skepsis til kvindesporten blev der i 1967 introduceret en »feminin kontrol «, den såkaldte sex-chromantin test, og testen blev som omtalt benyttet ved OL første gang i Mexico. Det kan konstateres, at kun få kvinder er blevet diskvalificeret, hvilket får visse teoretikere til at udtale, at de kvinder, hvis »sexstatus var diskutabel« frivilligt valgte at forlade sportens arena (13).

Eliteidrættens kvinder kan fortælle spændende kvindehistorie, for de overskred grænsen til et offentligt liv, de nægtede, at de alene var en biologisk og uforanderlig størrelse, de stillede krav om at blive opfattet som en samfundsmæssig og kulturel personlighed. De afdækkede nogle af myterne om kvinders liv, men også nogle af sportens myter - måske fordi de blev udfordret til kamp.

\section{Noter og litteraturoversigt}

1) Sandblad, Henrik, Olympia och Valhalla, Idehistoriske aspekter av den moderne idrottsrorelsens framvakst, Göteborg 1985, side 114

2) Simri, Uriel, Women at the Olympis Games, Israel 1979...side 13. Simris værk er baseret på et meget stort litteraturstudie, og der er således en mængde nyttige henvisninger for de, som $\varnothing$ nsker at arbejde med kvinders OL-historie.

3) Simri, Uriel, Women........side 26-30

4) Lobedanz, A, Efterskrift til Fressel, Hvad enhver Cyclist bør vide, København 1895 side 59. Se endvidere her Hans Bonde, En stålsat karakter i et hærdet legeme, speciale fra Historisk Institut, KU 1986. 
5) Rosenbeck, Bente, Kvindekøn, Den moderne kvindeligheds historie $1880-1980$, København 1987, side 48

6) Howitz, Fr., Bidrag til en sundhedslære for Kvinder, København 1892...side 35

7) Howitz, Fr., Bidrag.....side 41

8) Simri, Uriel, Women.....side 26-30

9) Talbot, Margaret, artikel i The British Journal of Physical Education No 1, 1988, „Women and the Olympis Games« side 11

10) Idorn, John, De.....side 122

11) Augested, Liv Berit, Menstruatjon og idrett, artikel i Kvinner og idrett, Fra myte til realitet, Oslo $1982 \ldots$ side $115-130$

12) Hagenfeldt, Kerstin, Hormonelle forstyrelser hos kvinder ved fysisk aktivitet, indlæg på seminarrapport fra DIF 1985 om »At træne piger/kvinder « side 21-30

13) Simri, Uriel, Women.....side 67-68

Else Trangbæk, lic. phil. i historie, ansat som adjunkt ved Danmarks Højskole for Legems $\varnothing v e l s e r$ og formand for Dansk Idrætshistorisk Forening - Krop og Kultur. 